УДК 631.46:57.045:911.9

\title{
ПОВЫШЕНИЕ ЭФФЕКТИВНОСТИ РЕМЕДИАЦИИ НЕФТЕЗАГРЯЗНЕННЫХ ПОЧВ В ПРИРОДНО-КЛИМАТИЧЕСКИХ УСЛОВИЯХ СЕВЕРА ТОМСКОЙ ОБЛАСТИ И СОПРЕДЕЛЬНЫХ РЕГИОНОВ С ПРИМЕНЕНИЕМ АБОРИГЕННЫХ МИКРООРГАНИЗМОВ
}

\author{
Франк Юлия Александровна $1,2,3$, \\ yulia.a.frank@gmail.com
}

\author{
Никитчук Ксения Леонидовна 1 , \\ k.nikitchuk@yandex.ru
}

\section{Сапега Алексей Александрович1,4, darwin.2014@mail.ru}
Лукьянова Евгения Александровна 3 , bio.darwin@mail.ru

\author{
Ивасенко Денис Александрович1,3, \\ ivasenko.da@mail.ru
}

\author{
Косов Антон Владимирович4, \\ darwin.2014@mail.ru
}

Герасимчук Анна Леонидовна1,
gerasimchuk_ann@mail.ru

\section{Евсеева Нина Степановна ${ }^{1}$, geography@ggf.tsu.ru}

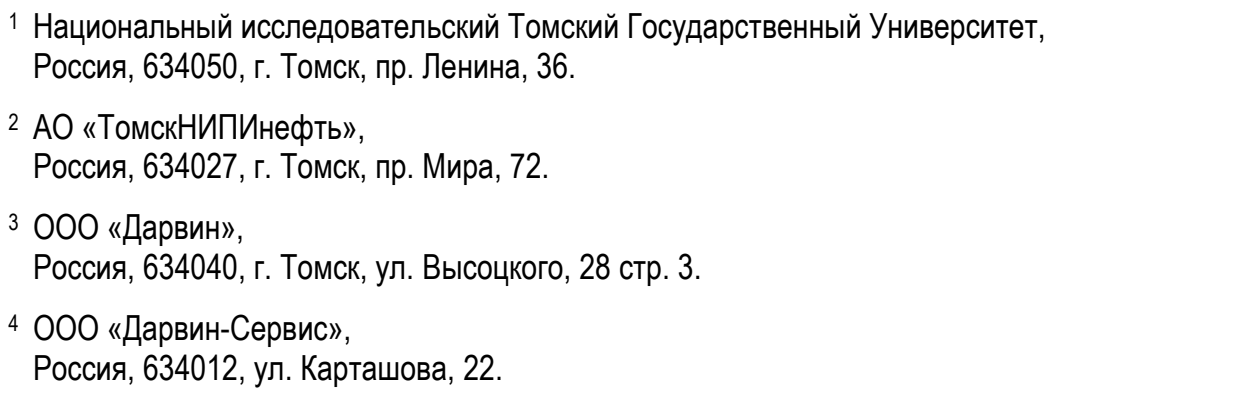

Актуальность исследования. Наибольшая антропогенная нагрузка, связанная с эксплуатацией природных ресурсов в Томской области, приходится на нефтегазодобывающую промышленность. Геоэкологический анализ территории показал, что наиболее уязвимыми участками являются северные административные районы, при этом основной фактор нефтяного загрязнения почв - аварии на трубопроводах. Биоремедиация является низкозатратным и экологичным методом восстановления нарушенных территорий. Эфрфективный подход к биоремедиации нефтезагрязненных почв заключается в выделении аборигенных микроорганизмов-деструкторов углеводородов и создании биопрепаратов на их основе.

Цель: разработать промышленный консорциум на основе аборигенных углеводородокисляющих бактерий из почв Севера Томской области и оценить его эфффективность для биоремедиации нефтезагрязненных почв.

Объекты и методы. Культуры аборигенных углеводородокисляющих микроорганизмов получены в селективных условиях из образца почвы Советского месторождения нефти Томской области, загрязненной сырой нефтью. Выделенные штаммы идентифицировали с использованием молекулярно-генетических методов на основе анализа последовательностей гена $16 \mathrm{~S}$ рРНК. Изучение фризиологических и биохимических свойств изолятов выполняли стандартными методами, морфологию клеток изучали микроскопически. Для оценки эфффективности биопрепарата на основе выделенных итаммов проводили полевые испытания на нефтезагрязненных участках. Количественный химический анализ на суммарное содержание нефттепродуктов в почве выполняли фрлуориметрическим методом.

Результаты. В ходе исследования из нефтезагрязненных почв в Томской области выделены и охарактеризованы 3 новых штамма углеводородокисляющих бактерий, принадлежащие к родам Acinetobacter и Oleomonas. Аборигенные микроорганизмы характеризуются сниженными оптимумами температуры и рН по сравнению с типовыми штаммами. На основе выделенных микроорганизмов разработан коммерческий биопрепарат «Абориген», предназначенный для биоремедиации нефртезагрязненных почв и ветландов. Экспериментальное восстановление нефртезагрязненных почв с помощью препарата аборигенных микроорганизмов-биодеструкторов позволило значительно сократить сроки по сравнению с самостоятельным восстановлением почвенного покрова в ходе естественных процессов. Полевые испытания показали высокую эффрективность деструкции нефти под действием биопрепарата - в среднем по восьми опытным участкам суммарное содержание нефттепродуктов в почве было снижено в 12,4 раз за три месяца.

\section{Ключевые слова:}

Нефтяное загрязнение почв, биоремедиация, аборигенные микроорганизмы, микробные консорциумы, загрязнение окружающей среды, нефтегазодобывающая промышленность.

\section{Введение}

Томская область является одним из стратегически важных регионов мирового масштаба, влияющих на сохранение глобального гомеостаза планеты. Это обусловлено тем, что, во-первых, на данной территории расположена большая часть Васюганского болота ценность которого заключается в понижении парни- кового эффекта на всей Земле. Во-вторых, в недрах области сосредоточены богатейшие ресурсы железной руды, торфа, значительные запасы нефти и газа и других полезных ископаемых, важность которых возрастает в связи с истощением ресурсов в регионах РФ и мира. В «Стратегии социально-экономического развития Томской области до 2030 года» отмечается, что 
богатые природные ресурсы являются конкурентным её преимуществом, а их рациональное и устойчивое использование - важным фактором экономического развития [1]. Как отмечает Н.И. Лаптев [2], недооценка природных ресурсов может привести к стратегическим и тактическим ошибкам в планировании развития при проведении региональной экологической политики и при принятии управленческих решений в условиях рыночной экономики, появлению негативных тенденций в развитии региона.

Воздействие нефтегазовых объектов на окружающую среду проявляется на всех стадиях освоения, начиная со строительства объектов и скважин и заканчивая переработкой углеводородного сырья. Число аварий на объектах нефтедобычи и транспортировки нефти ежегодно достигает порядка 25 тысяч инцидентов, в результате чего около 1,5 млн т нефти поступает в окружающую среду [3]. В настоящее время эксплуатация природных ресурсов Томской области осуществляется тремя отраслями: нефтегазодобывающей, лесозаготовительной и агропромышленной. Наибольшая антропогенная нагрузка в регионе приходится на нефтегазодобывающую промышленность. По состоянию на начало 2018 г. в области открыто 137 месторождений углеводородов, включая 106 нефтяных, 21 нефтегазоконденсатное, 10 газоконденсатных [4].

Геоэкологический анализ территории Томской области показал, что наиболее уязвимыми участками являются северные административные районы: Александровский, Каргасокский и Парабельский [5], что обусловлено интенсивным развитием нефтегазодобывающей промышленности на Севере области. Здесь же отмечается наибольшая концентрация загрязнения атмосферного воздуха - более 70 \% от общего объема поступающих выбросов всей области. Одна из причин негативного воздействия на окружающую природную среду - аварийность на объектах нефтегазодобывающего комплекса, вызванная отказами трубопроводов на нефтепроводах, на водоводах. Порывы трубопроводов и последующие аварийные разливы нефти и нефтепродуктов наряду с обеспечением экологической безопасности ликвидированных и законсервированных скважин относят к основным угрозам возникновения чрезвычайных ситуаций техногенного характера в сфере недропользования [6]. Аварийные ситуации были отмечены на месторождениях Катыльгинское, Лугинецкое, Ломовое, Первомайское, Игольско-Таловое, Западно-Катыльгинское, Крапивинское, Малореченское, Оленье, Лонтынь-Ях, Советское, Чкаловское. Общий показатель аварийных ситуаций за период с 2013 до 2017 гг. составляет порядка 1100 (преимущественно на месторождениях ОАО «Томскнефть» ВНК) [4, 7-9].

Современные методы для ликвидации нефтяного загрязнения ландшафтов включают химические, физико-химические, термические, электрические и электромагнитные, акустические и ультразвуковые, а также биологические методы [10]. Биоремедиация подход, который использует метаболические возможности микроорганизмов для разложения или превращения органических загрязнителей в безвредные продукты путем минерализации $[11,12]$. Биоремедиация является эффективной, низкозатратной и не оказывает негативного воздействия на экосистемы [13]. Хотя эффективность биоремедиации может снижаться из-за специфических свойств загрязняющих веществ, физико-химических особенностей почвы и экологических факторов, этот процесс является одним из наиболее часто применяемых в практике очистки нефтезагрязненных ландшафтов. Одним из важных факторов, определяющих эффективность биоремедиации, является подбор активных штаммов микроорганизмов-деструкторов углеводородов нефти и разработка консорциумов на их основе. Известно, что в северных районах процессы биодеструкции углеводородов с участием аборигенной углеводородокисляющей микрофлоры замедлены, а универсальные биопрепараты для ремедиации почв при низких температурах недостаточно эффективны. Для сохранения природного потенциала севера, включая арктические и субарктические регионы, предложена разработка новых экологически безопасных способов борьбы с нефтяными загрязнениями, в основу которых может быть положено исследование аборигенной микрофлоры [14].

\section{Объекты и методы}

Для выделения чистых культур аборигенных углеводородокисляющих микроорганизмов с целью разработки биопрепарата использовали образец почвы, загрязненной сырой нефтью в концентрации $50 \ldots 60$ г/кг. Почву отбирали в 2014 г. на Советском месторождении нефти (Александровский р-н Томской обл.). Месторождение расположено на севере Томской области, на границе с ХМАО-Югрой.

Образец почвы отбирали в стерильную центрифужную пробирку объемом 50 мл с соблюдением асептических условий и хранили при $4{ }^{\circ} \mathrm{C}$ до начала лабораторных исследований. Первоначально была получена накопительная культура углеводородокисляющих микроорганизмов в селективных условиях. Использовали жидкую питательную среду (г/л: $\mathrm{KH}_{2} \mathrm{PO}_{4}-1,5$, $\mathrm{K}_{2} \mathrm{HPO}_{4}-0,75, \mathrm{NH}_{4} \mathrm{Cl}-1,0, \mathrm{NaCl}-2,5, \mathrm{MgSO}_{4} \times 7 \mathrm{H}_{2} \mathrm{O}-$ 0,2 , дрожжевой экстракт - 0,5) с сырой нефтью (1\%) в качестве основного источника углерода и электронов. Культивировали при $28{ }^{\circ} \mathrm{C}$ в условиях аэрации с использованием шейкера (160 об/мин). Выделение чистых культур проводили на агаризованной (15 г/л) среде того же состава методом изолирования отдельно лежащих колоний на чашках Петри.

Морфологию клеток микроорганизмов исследовали методом фазово-контрастной микроскопии с помощью микроскопа Биомед-6 с фазово-контрастным устройством при увеличении $\times 1000$, микрофотосъемку проводили с помощью светового микроскопа Axioskop 40 (CarlZeiss, Германия). Изучение физиологических и биохимических свойств изолятов выполняли стандартными методами [15].

Для идентификации каждого штамма проводили полимеразную цепную реакцию (ПЦР), амплифицируя фрагменты гена $16 \mathrm{~S}$ рРНК, близкие к полным, с использованием домен-специфичных праймеров $27 \mathrm{~F}$ и 
1387R [16, 17]. Для этого из отдельных колоний выделяли суммарную ДНК. ПЦР проводили на амплификаторе Dyad DNA Engine «BioRad» (США), с использованием HotStart Tаq-полимеразы производства «Сибэнзим» (Россия) и соответствующего буфера. Коммерческое секвенирование выполняли в ФБУН ГНЦ ВБ «Вектор» (г. Кольцово Новосибирской обл.) на секвенаторе AppliedBiosystems 3130xl («Hitachi») с использованием набора AB1 prismBigDyeterminator V3.1 cycle. Для секвенирования использовали продукты амплификации длиной 1360 пар оснований. Нуклеотидные последовательности генов $16 \mathrm{~S}$ рРНК анализировали с помощью программы BioEdit и инструмента BLAST [18] для поиска ближайших родственников в базе данных GenBankNCBI.

В ходе полевых испытаний в северных районах готовили рабочий раствор биопрепарата «Абориген» из расчёта 5 л на $2 \mathrm{~m}^{3}$ пресной воды, готовили количество рабочего раствора, достаточное для обработки участков. Для обеспечения микроорганизмов питательными веществами биопрепарат применяют совместно с растворёнными комплексными минеральными удобрениями (азофоска). Удобрения растворяются из расчёта 50 кг $/ \mathrm{M}^{3}$ воды. Внесение биопрепарата осуществляют с помощью мотопомпы из разборного резервуара или с автоцистерны после проведения работ по фрезерованию. В зависимости от начального уровня загрязнения для достижения максимальной эффективности рекомендуется дробное внесение биопрепарата, с промежутком в 2-3 недели (табл. 1).

Таблица 1. Схемы внесения биопрепарата «Абориген» и минеральных удобрений

Table 1. Application of «Aborigen» biopreparation and mineral fertilizers

\begin{tabular}{|c|c|c|}
\hline $\begin{array}{c}\text { Уровень за- } \\
\text { грязнения, г/кг } \\
\text { Contamination } \\
\text { level, g/kg }\end{array}$ & $\begin{array}{c}\text { Кратность } \\
\text { внесения } \\
\text { Number of } \\
\text { applications }\end{array}$ & $\begin{array}{l}\text { Норма внесения } \\
\text { на } 1 \text { гектар } \\
\text { Application norm } \\
\text { for } 1 \text { hectare }\end{array}$ \\
\hline \multirow{2}{*}{$<100$} & \multirow{2}{*}{$1-2$} & $\begin{array}{l}\text { Биопрепарат: 10/10 л } \\
\text { Biopreparation: 10/10 L }\end{array}$ \\
\hline & & $\begin{array}{c}\text { Азофоска: } 150 / 100 \text { кг } \\
\text { NPK mineral fertilizer 150/100 kg }\end{array}$ \\
\hline \multirow{2}{*}{$100-250$} & \multirow{2}{*}{$2-3$} & $\begin{array}{c}\text { Биопрепарат: 15/10 л } \\
\text { Biopreparation: } 15 / 10 \mathrm{~L}\end{array}$ \\
\hline & & $\begin{array}{c}\text { Азофоска: 200/100 кг } \\
\text { NPK mineral fertilizer: } 200 / 100 \mathrm{~kg}\end{array}$ \\
\hline \multirow[b]{2}{*}{$>250$} & \multirow[b]{2}{*}{3} & $\begin{array}{c}\text { Биопрепарат: 15/10/5 л } \\
\text { Biopreparation: 15/10/5 L }\end{array}$ \\
\hline & & 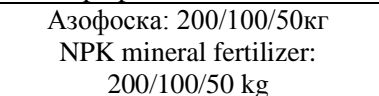 \\
\hline
\end{tabular}

Количественный химический анализ на суммарное содержание нефтепродуктов в почве проводили флуориметрическим методом с использованием анализатора жидкости «Флюорат-02» в соответствии с методикой ПНД Ф 16.1:2.21-98.

\section{Результаты и обсуждение}

Из нефтезагрязненных почв Советского месторождения нефти на севере Томской области выделены три штамма углеводородокисляющих бактерий, обозначенные E-1, E-2 и Е-3. С помощью молекулярно-биологических методов штаммы идентифицировали как принадлежащие к Proteobacteria (табл. 2). Сравнительный анализ нуклеотидных последовательностей гена $16 \mathrm{~S}$ рРНК штаммов Е-1 и Е-2 выявил их принадлежность к роду Acinetobacter, наиболее близкородственными валидно описанными представителями являются типовые штаммы видов $A$. junii и A. calcoaceticus, соответственно. Род Acinetobacter объединяет широко распространенных обитателей почвы, водных экосистем, включая сточные воды, они также заселяют продукты питания, отдельные представители могут вызывать оппортунистические инфекции [19]. Например, A. baumannii в ряде случаев был причиной внутрибольничных инфекций [20]. В связи с наличием данных об условной патогенности представителей Acinetobacter для выделенных штаммов был проведен анализ в ФБУН ГНЦ ВБ «Вектор» для исключения патогенных свойств, который показал отрицательный результат. Установлено, что штаммы E-1 и Е-3 относятся к негемолитическим, несахаролитическим ацинетобактерам, как и другие представители видов A. junii и A. calcoaceticus.

Сравнительный анализ фенотипических признаков и нуклеотидных последовательностей продуктов ПЦР, соответствующих гену $16 \mathrm{~S}$ рРНК штамма Е-2, выявил 97 \% гомологию с Oleomonas sp. SJ-1. Род Oleomonas был описан в 2002 г., типовой штамм выделен из загрязненных почв нефтяного месторождения в Японии [21]. В настоящее время род представлен единственным видом - Oleomonas sagaranensis. Выделенный нами штамм, возможно, относится к новому виду, т. к. степень гомологии последовательности гена $16 \mathrm{~S}$ pРНК ниже порогового значения, принятого в настоящее время для разделения бактериальных видов в $98,5 \%$ [22].

Штаммы E-1, Е-2 и Е-3 были депонированы в Коллекцию бактерий, бактериофагов и грибов ФБУН ГНЦ ВБ «Вектор» под номерами В-1316, В-1317 и В1318 , соответственно.

Таблица 2. Таксономическое положение выделенных штаммов углеводородокисляющих бактерий

Table 2. Taxonomic position of the isolated hydrocarbon-degrading strains

\begin{tabular}{|c|c|c|c|}
\hline $\begin{array}{c}\text { Таксон/Штамм } \\
\text { Тахол/Strain }\end{array}$ & $\begin{array}{c}\text { E-1 } \\
\text { (B-1316) }\end{array}$ & $\begin{array}{c}\text { E-2 } \\
(\mathrm{B}-1317)\end{array}$ & $\begin{array}{c}\text { E-3 } \\
(\mathrm{B}-1318)\end{array}$ \\
\hline Домен/Domain & Bacteria & Bacteria & Bacteria \\
\hline Тип/Phylum & Proteobacteria & Proteobacteria & Gammaproteobacteria \\
\hline Класс/Class & Gammaproteobacteria & Alphaproteobacteria & Pseudomonadales \\
\hline Порядок/Order & Pseudomonadales & Rhodospirillales & Moraxellaceae \\
\hline Семейство/Family & Moraxellaceae & Acetobacteraceae & Acinetobacter \\
\hline Род/Genus & Acinetobacter & Olemonas & Ocinetobacter calcoaceticus \\
\hline Вид/Species & Acinetobacter junii & Olemas . & Acteria \\
\hline
\end{tabular}


Штаммы Е-1 и Е-3 представлены грамотрицательными неподвижными клетками в виде толстых коротких палочек размерами $0,8 \ldots 1,0 \times 0,9 \ldots 2,0$ мкм, по форме приближающимися к коккам (рис. 1). Штамм Е-3 также представлен грамотрицательными неспорообразующими укороченными толстыми палочками, приближающимися к кокковой форме размерами $1,0 \ldots 1,5 \times 1,0 \ldots 2,5$ мкм (рис. 2). Расположены клетки одиночно, в парах или в коротких цепочках, неподвижны, капсулированы. Штамм Е-2 представлен грамотрицательными прямыми и слабоизогнутыми, подвижными палочками, расположенными по 1-2 и в коротких цепочках, размером $0,7 \times 2,0 \ldots 3,5$ мкм (рис. 1 )

Были проведены физиологические исследования выделенных штаммов, которые позволили выявить их отношение к кислороду, температурные предпочтения и оптимальные значения рН среды. Показано, что штамм Е-2 демонстрирует рост в аэробных условиях с оптимумом при $\mathrm{pH} 5,0 \ldots 7,0$ и температуре $20 \ldots 30{ }^{\circ} \mathrm{C}$ (рис. 2). Штамм не растет при температуре
10 и $42{ }^{\circ} \mathrm{C}$, слабый, следовый рост наблюдается при $37{ }^{\circ} \mathrm{C}$. Штамм E-1 является облигатным аэробом с оптимумом роста в диапазоне $\mathrm{pH} 5,0 \ldots 7,0$ и температуре $20 \ldots 30^{\circ} \mathrm{C}$, хорошим ростом при $\mathrm{pH} 9,0$ и температуре $20 \ldots 30{ }^{\circ} \mathrm{C}$ (рис. 2). Ослабленный рост штамма выявлен при $37^{\circ} \mathrm{C}, \mathrm{pH} 9,0$. Штамм не растет при температуре 10 и $42^{\circ} \mathrm{C}$ и при температуре $37^{\circ} \mathrm{C}$ и рН 5,0 и 7,0. Штамм Е-3 также является облигатным аэробом с оптимумом роста в диапазоне $\mathrm{pH} 5,0 \ldots 7,0$ при температуре $20 \ldots 30{ }^{\circ} \mathrm{C}$ (рис. 2). При $37^{\circ} \mathrm{C}$ и рН 7,0 и 9,0 рост более слабый. Способен к активному росту при pH 9,0 Штамм не растет при температуре 10 и $42{ }^{\circ} \mathrm{C}$. Микроорганизмы рода Acinetobacter обычно характеризуются более высокой оптимальной температурой $30 \ldots 32{ }^{\circ} \mathrm{C}$ и оптимумом рН около 7,0 [19]. Аборигенные штаммы Acinetobacter, выделенные в данной работе, как и штамм Oleomonas sp E-2, имеют более низкий оптимум температуры и $\mathrm{pH}$, что, наиболее вероятно, связано с региональными климатическими особенностями и особенностями северных почв.

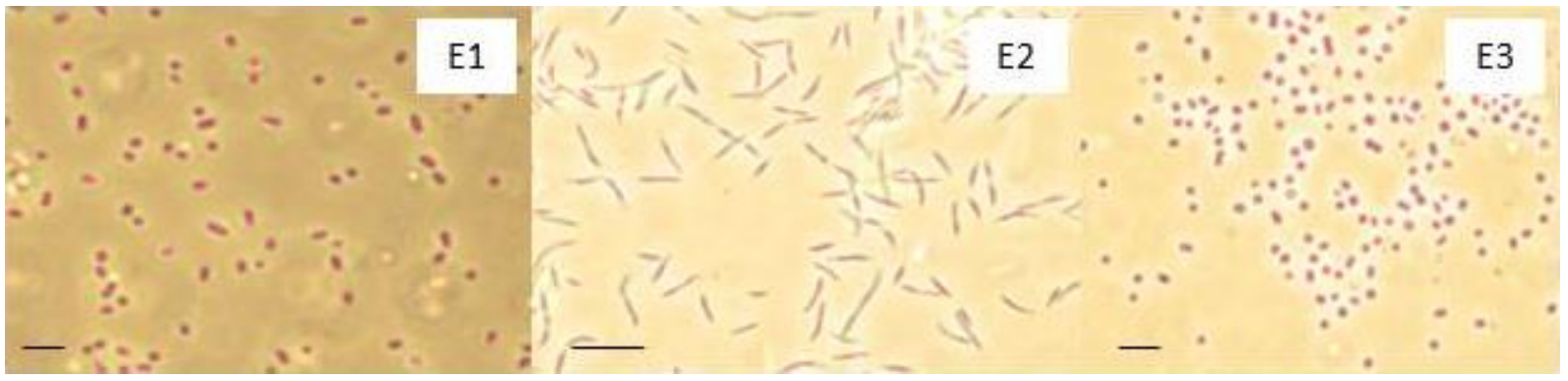

Pис. 1. Морфология клеток выделенных штаммов углеводородокисляющих бактерий, линейка 5 мкм

Fig. 1. Cell morphology of the isolated hydrocarbon-degrading strains, scale bar is $5 \mu \mathrm{m}$

Выделенные штаммы активно росли на питательных средах, содержащих сырую нефть или дизельное топливо с высоким содержанием циклопарафинов в качестве единственного источника углерода и электронов, и были включены в состав коммерческого биопрепарата «Абориген» для биоремедиации нефтезагрязненных почв. Биопрепарат «Абориген» производится Группой компаний «Дарвин» (ОOО «Дарвин-Сервис» и ООО «Дарвин», г. Томск) по ТУ 9291 001-28828893-2015. Представляет собой жидкий биопрепарат с плотностью микроорганизмов не менее $2,0 \times 10^{8}$ кл/мл (200 млн клеток в 1 мл). Рабочий раствор, применяемый для обработки почв и ветландов, содержит не менее $1,0 \times 10^{6}$ кл/мл. В ходе настоящего исследования были проведены полевые испытания биопрепарата, основанного на консорциуме аборигенных штаммов из загрязненных почв севера Томской области. Испытания проводили на загрязненных территориях в районах нефтегазодобычи, преимущественно в ХМАО-Югре, примыкающей к Томской области с севера, в летне-осенний период 2018 г. Территории отличаются суровыми погодноклиматическими условиями: резкоконтинентальный климат характеризуется суровой, многоснежной и продолжительной зимой, тёплым непродолжительным летом.
В ходе полевых испытаний на нефтезагрязненные участки вносили жидкий биопрепарат по схеме, указанной в табл. 1. Для обеспечения микроорганизмов доступными питательными веществами вместе с биопрепаратом вносили комплексное минеральное удобрение «Азофоска», NPK 16:16:16 (нормы внесения различаются в зависимости от исходного уровня загрязнения, табл. 1). Почву фрезеровали однократно для обеспечения аэрации и равномерного распределения микроорганизмов-деструкторов нефти. Мероприятия по технической рекультивации и фиторемедиации не проводили, чтобы оценить эффект биопрепарата углеводородокисляющих микроорганизмов. Отметим, что полный комплекс работ по рекультивации земель включает технический и биологический этапы. Технический этап рекультивации нарушенных земель является подготовительным для последующего биологического этапа и включает проведение планировочных работ, мероприятия по обеспечению стабильности грунтов, нанесение плодородного слоя почвы и потенциально плодородных пород при их наличии на рекультивируемые земли, при необходимости предусматривает коренную мелиорацию с учетом типов почв [23]. Биологический этап рекультивации нарушенных земель включает комплекс агротехнических, биологических и фитомелиоративных ме- 
роприятий по восстановлению качественного состояния земель, направленных на создание условий для восстановления экологических функций почв, их биологической продуктивности и биоразнообразия [23].

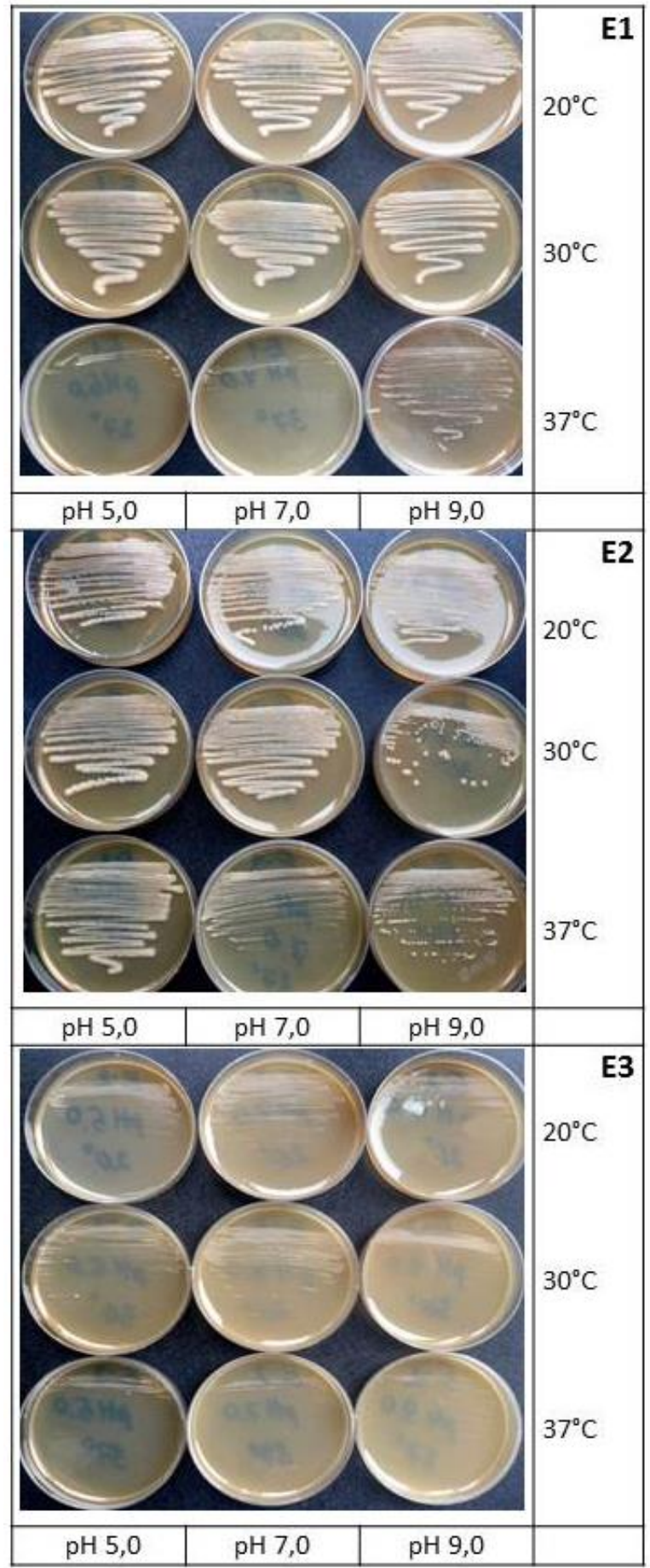

Puc. 2. Рост итаммов E1, Е2 и Е3 (сверху вниз) при различных температурах и $\mathrm{pH}$ среды

Fig. 2. Growth of the strains E1, E2 and E3 (top-down) at different temperatures and $\mathrm{pH}$

Для оценки эффективности сравнивали данные количественного химического анализа на суммарное содержание нефтепродуктов, выполненного до начала внесения биопрепарата и после завершения биологического этапа рекультивации. Сводные данные, полученные на разных участках рекультивации почв, представлены в табл. 3. Однократное применение биопрепарата с последующей экспозицией в течение трех месяцев позволило снизить концентрацию нефтепродуктов в почве в $3,0 \ldots 57,8$ раз, в среднем в 12,4 раз. Степень деградации компонентов сырой нефти в первую очередь зависит от исходной концентрации в почве. На участках 2-7 начальное содержание нефтепродуктов в почве было выше 60 г/кг, что сопоставимо с концентрациями нефтепродуктов в нефтешламах Вахского и Советского месторождений [24]. Тем не менее в этих сайтах концентрация нефтепродуктов в ходе полевого эксперимента была снижена минимум в 3,0 (участок 2), а максимум в 9,2 раза (участок 4).

На опытных участках, которые характеризовались обводненностью $25 \%$ и более, а также в сайтах, где на протяжении 30 суток и более температура окружающей среды составляла выше $17{ }^{\circ} \mathrm{C}$, концентрации нефтепродуктов в почве снизились наиболее заметно (участки №№ 1, 4, 8). Ранее установлено, что процесс разложения нефти под действием культивируемого консорциума из природного арктического бактериального комплекса запускается при $10{ }^{\circ} \mathrm{C}$ и выше, причем максимальная интенсивность биодеструкции наблюдается в первые 15 суток [14].

Таблица 3. Суммарное содержание нефтепродуктов (НП) в почве до внесения биопрепарата «Абориген» и по завершении биологического этапа рекультивации

Table 3. Total oil content in soil before the application of «Aborigen» preparation and after finishing the work

\begin{tabular}{|c|c|c|}
\hline $\begin{array}{c}\text { Опыт- } \\
\text { учй } \\
\text { Test site }\end{array}$ & $\begin{array}{c}\text { Содержание НП до вне- } \\
\text { сения препарата, мг/кг } \\
\text { Oil content before the } \\
\text { application of the } \\
\text { preparation, } \mathrm{mg} / \mathrm{kg}\end{array}$ & $\begin{array}{c}\text { Содержание НП по } \\
\text { окончании работ, } \\
\text { мг/кг } \\
\text { Oil content after } \\
\text { finishing the work, } \\
\mathrm{mg} / \mathrm{kg}\end{array}$ \\
\hline 1 & $39527 \pm 9882$ & $4096 \pm 1024$ \\
\hline 2 & $60155 \pm 15039$ & $>20000$ \\
\hline 3 & $>100000$ & $>20000$ \\
\hline 4 & $>100000$ & $10813 \pm 2703$ \\
\hline 5 & $>100000$ & $>20000$ \\
\hline 6 & $>100000$ & $>200000$ \\
\hline 7 & $52136 \pm 13034$ & $901 \pm 225$ \\
\hline 8 & & \\
\hline
\end{tabular}

Визуально в процессе опытной биоремедиации загрязненных участков пятна нефти изменяли цвет от черного до светло-коричневого, а в местах наиболее активных микробиологических процессов наблюдался рыжеватый цвет грунта. Данные изменения характерны для активной деятельности углеводородокисляющих микроорганизмов, которые ускоряют процесс деструкции нефти. Вид одного из загрязненных участков, на котором проводили полевые испытания, до внесения биопрепарата и по завершении работ представлен на рис. 3. 

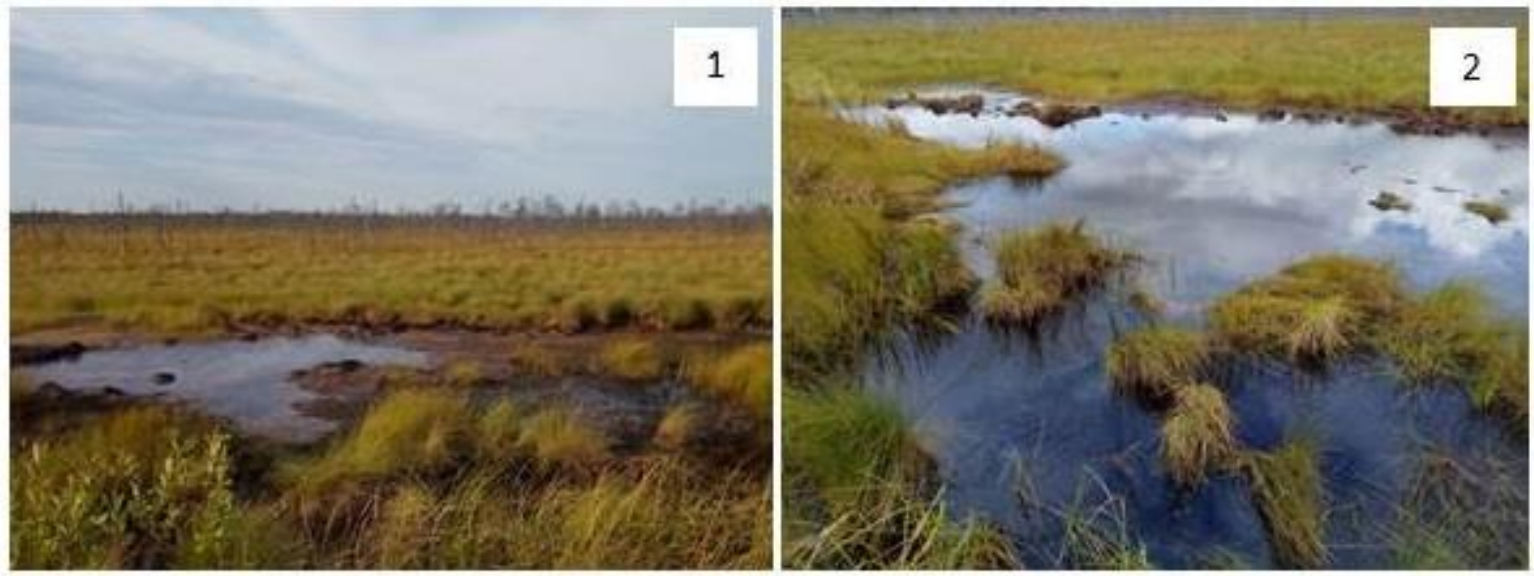

Рис. 3. Опытный участок до внесения биопрепарата и после окончания работ

Fig. 3. Testing site before the application of the biopreparation and after finishing the work

Мы прогнозируем, что применение биоремедиации с использованием препарата, содержащего клетки аборигенных штаммов, в совокупности с технической рекультивацией и фитомелиорацией позволит добиться еще более заметного снижения суммарной концентрации нефтепродуктов в почвах.

Дополнительной мерой по оптимизации природопользования может стать проведение рейдовых осмотров при наделении полномочиями общественных инспекторов представителей коренных малочисленных народов (хантов, эвенков), исконно населяющих данные территории. Комплексные наблюдения и мониторинг состояния окружающей среды в установленные сроки (квартал, месяц, год и др.) позволит оценить степень ее изменений с учётом интеграции традиционных экологических знаний коренных малочисленных народов и научных знаний [25], что будет способствовать сохранению территорий Томской области в первозданном виде, а также национально-культурных традиций коренных малочисленных народов.

\section{Заключение}

Таким образом, из нефтезагрязненных почв Советского месторождения нефти в Томской области выделены и охарактеризованы новые штаммы углеводородокисляющих бактерий, принадлежащие к

\section{СПИСОК ЛИТЕРАТУРЫ}

1. Стратегия социально-экономического развития Томской области до 2030 года. Постановление Законодательной Думы Томской области от 26.03.2015 N 2580. URL: https://www.tomsk.gov.ru/ctrategija-sotsialno-ekonomicheskogorazvitija-tomskoj-oblasti-do-2030-goda (дата обращения 09.06.2020).

2. Лаптев Н.И. Риски и надежность индикаторов устойчивого развития. URL: http://tele-conf.ru/problemyi-ekologii-izhiznedeyatelnosti-cheloveka/riski-i-nadezhnost-indikatorovustoychivogo-razvitiya.html (дата обращения 09.06.2020).

3. Кошановская В.С. Разливы нефти в Российской федерации: причины и пути решения проблемы // Экология: IX Международный форум. - М., 2018. - С. 13-18.

4. Государственный доклад «О состоянии и охране окружающей среды Томской области в 2018 году» / гл. ред. Ю.В. Лунева. Ижевск: Изд-во ООО «Принт», 2019. - 144 с

5. Никитчук К.Л., Хазиахметова Ю.А. Оптимизация регионального природопользования с учетом этнокультурной специфи- родам Acinetobacter и Oleomonas. Аборигенные микроорганизмы характеризуются сниженными оптимумами температуры и $\mathrm{pH}$ по сравнению с типовыми штаммами. Выделенные микроорганизмы составили основу коммерческого биопрепарата «Абориген» для биоремедиации нефтезагрязненных почв и ветландов.

Восстановление нефтезагрязненных почв с помощью препарата аборигенных микроорганизмовбиодеструкторов позволило значительно сократить сроки по сравнению с самостоятельным восстановлением почвенного покрова в ходе естественных процессов. Полевые испытания показали высокую эффективность деструкции нефти под действием биопрепарата - в среднем по восьми опытным участкам суммарное содержание нефтепродуктов в почве было снижено в 12,4 раз за три месяца.

Эффективность использования метода на территориях, нарушенных объектами нефтегазовой отрасли, на наш взгляд, позволит стабилизировать геоэкологическую ситуацию на Севере Томской области.

Исследование частично выполнено по заданию Министерства науки и высшего образования (проект № 0721 2020-0019). Авторы благодарят Рыбкина Данилу Сергеевича за помощь в проведении полевых испытаний биопрепаpama.

ки местности (на примере Томской области) // Проблемы региональной экологии. - 2019. - № 4. - С. 68-72.

6. Орлов В.П. Проблемы недропользования (2000-2006). - М.: Геоинформмарк, Геоинформ, 2007. - 464 c.

7. Никитчук К.Л., Чурилова Т.А. Аварийность на объектах нефтегазодобывающего комплекса и техногенные чрезвычайные ситуации // Госдоклад «О состоянии и охране окружающей среды Томской области в 2014 году». - Томск: Дельтаплан, 2015. - С. 73-75.

8. Никитчук К.Л. Аварийность на объектах нефтегазодобывающего комплекса и техногенные чрезвычайные ситуации // Госдоклад «О состоянии и охране окружающей среды Томской области в 2015 году». - Томск: Дельтаплан, 2016. C. $74-75$.

9. Никитчук К.Л. Аварийность на объектах нефтегазодобывающего комплекса и техногенные чрезвычайные ситуации // Госдоклад «О состоянии и охране окружающей среды Томской области в 2016 году». - Ижевск: Изд-во ООО «Принт-2», 2017 - C. $81-82$ 
10. Remediation of soil and water contaminated with petroleum hydrocarbon: a review / I.C. Ossai, A. Ahmed, A. Hassan, F.S. Hamid // Environmental Technology \& Innovation. - 2020. V. 17. - 100526. DOI: 10.1016/j.eti.2019.100526.

11. Bioremediation of petroleum oil contaminated soil and water $/$ P.K. Jain, V.K. Gupta, R.K. Gaur, M. Lowry, D.P. Jaroli, U.K. Chauhan // Research Journal of Environmental Toxicology. 2011. - V. 5. - P. 1-26.

12. Clean-up of crude oil-contaminated soils: bioremediation option/ E. Okoh, Z.R. Yelebe, B. Oruabena, E.S. Nelson, O.P. Indiamaowei // International Journal of Environmental Science and Technology. - 2020. - V. 17. - P. 1185-1198.

13. Yuniati M.D. Bioremediation of petroleum-contaminated soil: a review // IOP Conference Series: Earth and Environmental Science. 2018. - V. 118. - 012063. DOI: 10.1088/1755-1315/118/1/012063.

14. Наливайко Н.Г., Иванова И.С. Роль природного арктического бактериального комплекса в процессах биодеструкции нефти // Энерго-ресурсоэффективность в интересах устойчивого развития: Международная научная конференция. - Томск: Изд-во ТПУ, 2018. - С. 170-171

15. Bergey's manual of systematic bacteriology. V. 2: The Proteobacteria / Ed. By G. Garrity - US: Springer, 2005. - 2816 p.

16. DeLong E.F. Archaea in costal marine environments // Proceedings of the National Academy of Sciences of the USA. 1992. - V. 89. - P. 5685-5689.

17. Design and evaluation of useful bacterium-specific PCR primers that amplify genes coding for bacterial $16 \mathrm{~S}$ rRNA / J.R. Marchesi, T. Sato, A.J. Weightman, T.A. Martin, J.C. Fry, S.J. Hiom, W.G. Wade // Applied and Environmental Microbiology. 1998. - V. 64. - P. 795-799.

18. Gapped BLAST and PSI-BLAST: a new generation of protein database search programs / S. F. Altschul, T. L. Madden, A.A. Schäffer, J. Zhang, Z. Zhang, W. Miller, D.J. Lipman // Nucleic Acids Research. - 1997. - V. 25. - P. 389-402.
19. Towner K. The Genus Acinetobacter // The Prokaryotes. V. 6: Proteobacteria: Gamma Subclass. - Singapore: Springer Science+Business Media, 2006. - P. 746-758.

20. Moubareck C.A., Halat D.H. Insights into Acinetobacter baumannii: a review of microbiological, virulence, and resistance traits in a threatening nosocomial pathogen // Antibiotics. 2020. - V. 9. - 119. DOI: 10.3390/antibiotics9030119.

21. Oleomonas sagaranensis gen. nov., sp. nov., represents a novel genus in the $\alpha$-Proteobacteria / T. Kanamori, N. Rashid, M. Morikawa, H. Atomi, T. Imanaka // FEMS Microbiology Letters. - 2002. - V. 217. - P. 255-261

22. Proposed minimal standards for the use of genome data for the taxonomy of prokaryotes / J. Chun, A. Oren, A. Ventosa, H. Christensen, D.R. Arahal, M.S. da Costa, A.P. Rooney, H. Yi, X.-W. Xu, S. de Meyer, M.E. Trujillo // International Journal of Systematic and Evolutionary Microbiology. - 2018. - V. 68. P. 461-466.

23. ГОСТ Р 57446-2017. Наилучшие доступные технологии. Рекультивация нарушенных земель и земельных участков. Восстановление биологического разнообразия. - М.: Стандартинформ, 2017. $-28 \mathrm{c}$.

24. Алтунина Л.К. и др. Каталитические, сорбционные, микробиологические и интегрированные методы для защиты и ремедиации окружающей среды / под ред. О.П. Таран, В.Н. Пармона. - Новосибирск: Изд-во СО РАН, 2013. - 298 с.

25. Никитчук К.Л. Перспективы внедрения традиционных экологических знаний коренных малочисленных народов в практику охраны окружающей среды и рационального природопользования // Общество. Среда. Развитие. - 2016. - № 1 (38). C. $87-91$.

Поступила 01.06.2020 г.

\section{Информация об авторах}

Франк Ю.А., кандидат биологических наук, доцент, заведующая лабораторией промышленной микробиологии Биологического института Национального исследовательского Томского Государственного Университета; ведущий инженер отдела комплексных экологических проектов АО «ТомскНИПИнефть»; заместитель директора по научной работе ООО «Дарвин».

Никитчук К.Л., старший преподаватель кафедры экологии, природопользования и экологической инженерии Биологического института Национального исследовательского Томского Государственного Университета.

Caneza A.A., магистрант Биологического института Национального исследовательского Томского Государственного Университета; технолог ООО «Дарвин-Сервис».

Лукьянова Е.A., кандидат биологических наук, заместитель директора по качеству ООО «Дарвин».

Ивасенко Д.А., старший преподаватель кафедры физиологии растений и биотехнологии Биологического института Национального исследовательского Томского Государственного Университета; директор ООО «Дарвин».

Косов А.В., директор ООО «Дарвин-Сервис».

Герасимчук А.Л., кандидат биологических наук, старший научный сотрудник научно-исследовательской лаборатории биологии и почвоведения Биологического института Национального исследовательского Томского Государственного Университета.

Eвсеева H.C., доктор географических наук, заведующая кафедрой географии Геолого-географического факультета Национального исследовательского Томского Государственного Университета. 
UDC 631.46:57.045:911.9

\section{IMPROVEMENT OF THE EFFICIENCY OF OIL-CONTAMINED SOILS REMEDIATION IN THE NATURAL CONDITIONS OF THE NORTH TOMSK REGION AND THE NEARBY REGIONS BY INDIGENOUS MICROORGANISMS APPLICATION}

Yulia A. Frank ${ }^{1,2,3}$, yulia.a.frank@gmail.com

Ksenia L. Nikitchuk', k.nikitchuk@yandex.ru

Alexey A. Sapega ${ }^{1,4}$, darwin.2014@mail.ru

Evgenia A. Lukyanova ${ }^{3}$, bio.darwin@mail.ru

Denis A. Ivasenko ${ }^{1,3}$, ivasenko.da@mail.ru

Anton V. Kosov 4 , darwin.2014@mail.ru

Anna L. Gerasimchuk1, gerasimchuk_ann@mail.ru

Nina S. Evseeva ${ }^{1}$, geography@ggf.tsu.ru

1 National Research Tomsk State University, 36, Lenin avenue, Tomsk, 634050, Russia.

2 «TomskNIPIneft» JSC,

72, Mira avenue, Tomsk, 634027, Russia.

3 «Darwin» LLC,

28/3, Vysotsky street, Tomsk, 634040, Russia.

4 «Darwin-Service» LLC,

22, Kartashov street, Tomsk, 634012, Russia.

The relevance of the study. The largest anthropogenic pressure associated with the exploitation of natural resources in the Tomsk region falls on the oil and gas industry. Geoecological analysis of the territory showed that the northern administrative regions are the most vulnerable areas, while the main factor in oil pollution of the soil is pipeline accidents. Bioremediation is a low-cost and environmentally friendly method of restoring contaminated areas. An effective approach to the bioremediation of oil-contaminated soils is isolation indigenous hydrocarbon-degrading microorganisms and creation biological products based on the strains.

The main aim of the study is developing an industrial consortium based on indigenous hydrocarbon-oxidizing bacteria from soils of the North Tomsk Region and evaluating its effectiveness for bioremediation of oil-contaminated soils.

Objects and methods. Cultures of indigenous hydrocarbon-oxidizing microorganisms were obtained under selective conditions from the crude oil contaminated soil sample, Soviet oil field, Tomsk Region. Isolated strains were identified using molecular genetic methods based on the analysis of 16S rRNA gene sequences. The physiological and biochemical properties of the isolates were studied by standard methods, and the morphology of the cells was studied microscopically. To assess the effectiveness of a biological product based on the selected strain, field tests were carried out in oil-contaminated areas. Quantitative chemical analysis for the total content of petroleum products in the soil was performed by fluorimetric method.

Results. During the study, three novel strains of hydrocarbon-oxidizing bacteria belonging to the genera Acinetobacter and Oleomonas were isolated from oil-contaminated soils in the Tomsk Region and characterized. Indigenous microorganisms are characterized by reduced optimums of temperature and $\mathrm{pH}$ in comparison with type strains. Based on the identified microorganisms, a commercial biological product «Aborigen» was developed for bioremediation of oil-contaminated soils and wetlands. The experimental restoration of oilcontaminated soils with the help of a preparation of indigenous microorganisms-destructors has significantly reduced the time compared to self-restoration of soil cover during natural processes. Field tests showed high efficiency of oil destruction under the influence of a biological product - on average, in eight experimental sites, the total content of oil products in the soil was reduced 12,4 times in three months.

\section{Key words:}

Crude oil contamination of soil, bioremediation, indigenous microorganisms,

microbial consortia, environmental pollution, oil and gas industry. 
The research was partially carried out by the task of the Ministry of Science and Higher Education (project no. 0721-2020-0019).

The authors express thanks to Danil S. Rybkin for assistance in biopreparation field study.

\section{REFERENCES}

1. Strategiya sotsialno-ekonomicheskogo razvitiva Tomskoy oblasti do 2030 goda. Postanovlenie Zakonodatelnoy Dumy Tomskoy oblasti ot 26.03.2015 N 2580 [Strategy for the socio-economic development of the Tomsk region until 2030. Decree of the Legislative Duma of the Tomsk Region dated 26.03.2015 N 2580]. Available at: https://www.tomsk.gov.ru/ctrategija-sotsialnoekonomicheskogo-razvitija-tomskoj-oblasti-do-2030-goda (accessed 09 June 2020).

2. Laptev N.I. Riski i nadezhnost indikatorov ustoychivogo razvitiya [Risks and reliability of indicators of sustainable development]. Available at: http://tele-conf.ru/problemyi-ekologii-izhiznedeyatelnosti-cheloveka/riski-i-nadezhnost-indikatorovustoychivogo-razvitiya.html (accessed 09 June 2020).

3. Koshanovskaya V.S. Razlivy nefti v Rossiyskoy Federatsii: prichiny i puti resheniya problem [Oil spills in the Russian Federation: causes and solutions]. IX Mezhdunarodny forum. Ekologiya [IX International Forum. Ecology]. Moscow, 2018. pp. 13-18.

4. Gosudarstvenny doklad «O sostoyanii i oлhrane okruzhayushchey sredy Tomskoy oblasti v 2018 godu» [State Report «On the State and Protection of the Environment in Tomsk Region in 2018»]. Ed. by Yu.V. Luneva. Izhevsk, Print LLC, 2019. 144 p

5. Nikitchuk K.L., Khaziakhmetova Yu.A. Optimization of regional nature management due to ethnocultural specicity of the area: a case study of the Tomsk region). Regional Environmental Issues, 2019, vol. 4, pp. 68-72.

6. Orlov V.P. Problemy nedropolzovaniya [Issues of subsoil use (2000-2006)]. Moscow, Geoinformmark, Geoinform Publ., 2007. $464 \mathrm{p}$.

7. Nikitchuk K.L., Churilova T.A. Avariynost na obektakh neftegazodobyvayushchego kompleksa i tehhnogennye chrezvychaynye situatsii [Accidents at the facilities of the oil and gas production complex and man-made emergencies]. Gosudarstvenny doklad «O sostoyanii $i$ okhrane okruzhayuschey sredy Tomskoy oblasti $v$ 2014 godu» [State Report «On the State and Protection of the Environment in Tomsk Region in 2014»]. Tomsk, Deltaplan Publ., 2015. pp. 73-75.

8. Nikitchuk K.L. Avariynost na obektah neftegazodobyvayushchego kompleksa i tehhnogennye chrezvychaynye situatsii [Accidents at the facilities of the oil and gas production complex and man-made emergencies]. Gosudarstvenny doklad «O sostoyanii $i$ okhrane okruzhayuschey sredy Tomskoy oblasti v 2015 godu» [State Report «On the State and Protection of the Environment in Tomsk Region in 2015»]. Tomsk, Deltaplan Publ., 2016. pp. 74-75.

9. Nikitchuk K.L. Avariynost na obektakh neftegazodobyvayushchego kompleksa i tekhnogennye chrezvychaynye situatsii [Accidents at the facilities of the oil and gas production complex and manmade emergencies]. Gosudarstvenny doklad «O sostoyanii $i$ okhrane okruzhayushchey sredy Tomskoy oblasti v 2016 godu» [State Report «On the State and Protection of the Environment in Tomsk Region in 2016»]. Izhevsk, Print LLC, 2017. pp. 81-82.

10. Ossai I.C., Ahmed A., Hassan A., Hamid F.S. Remediation of soil and water contaminated with petroleum hydrocarbon: a review. Environmental Technology \& Innovation, 2020, vol. 17, 100526. DOI: 10.1016/j.eti.2019.100526.

11. Jain P.K., Gupta V.K., Gaur R.K., Lowry M., Jaroli D.P., Chauhan U.K. Bioremediation of petroleum oil contaminated soil and water. Research Journal of Environmental Toxicology, 2011, vol. 5, pp. 1-26.

12. Okoh E., Yelebe Z.R., Oruabena B., Nelson E.S., Indiamaowei O.P. Clean-up of crude oil-contaminated soils: bioremediation option. International Journal of Environmental Science and Technology, 2020, vol. 17, pp. 1185-1198.

13. Yuniati M.D. Bioremediation of petroleum-contaminated soil: a review. IOP Conference Series: Earth and Environmental Science, 2018, vol. 118, 012063. DOI: 10.1088/1755-1315/118/1/012063.

14. Nalivaiko N.G., Ivanova I.S. Rol prirodnogo arkticheskogo kompleksa $v$ protsessakh biodestruktsii nefti [The role of the natural Arctic bacterial complex in oil biodegradation processes]. Mezhdunarodnaya nauchnaya konferentsia. Energoresursoeffectivnost $v$ interesakh ustoychivogo razvitia [International Scientific Conference. Energy and Resource Efficiency for Sustainable Development]. Tomsk, TPU Publ., 2018. pp. 170-171.

15. Bergey's manual of systematic bacteriology. Vol. 2: The Proteobacteria. Ed. by G. Garrity. US, Springer, 2005. 2816 p.

16. DeLong E.F. Archaea in costal marine environments. Proceedings of the National Academy of Sciences of the USA, 1992, vol. 89, pp. 5685-5689.

17. Marchesi J.R., Sato T., Weightman A.J., Martin T.A., Fry J.C., Hiom S.J., Wade W.G. Design and evaluation of useful bacteriumspecific PCR primers that amplify genes coding for bacterial $16 \mathrm{~S}$ rRNA. Applied and Environmental Microbiology, 1998, vol. 64, pp. 795-799.

18. Altschul S.F., Madden T.L., Schäffer A.A., Zhang J., Zhang Z., Miller W., Lipman D.J. Gapped BLAST and PSI-BLAST: a new generation of protein database search programs. Nucleic Acids Research, 1997, vol. 25, pp. 389-402.

19. Towner K. The Genus Acinetobacter. The Prokaryotes. Vol. 6: Proteobacteria: Gamma Subclass. Ed. by M. Dworkin, S. Falkow, E. Rosenberg, K.-H. Schleifer, E. Stackebrandt Singapore, Springer Science+Business Media, 2006. pp. 746-758.

20. Moubareck C.A., Halat D.H. Insights into Acinetobacterbaumannii: a review of microbiological, virulence, and resistance traits in a threatening nosocomial pathogen. Antibiotics, 2020, vol. 9, 119. DOI: 10.3390/antibiotics9030119.

21. Kanamori T., Rashid N., Morikawa M., Atomi H., Imanaka T. Oleomonassagaranensis gen. nov., sp. nov., represents a novel genus in the $\alpha$-Proteobacteria. FEMS Microbiology Letters, 2002, vol. 217, pp. 255-261.

22. Chun J., Oren A., Ventosa A., Christensen H., Arahal D. R., da Costa M.S., Rooney A.P., Yi H., Xu X.-W., De Meyer S., Trujillo M.E. Proposed minimal standards for the use of genome data for the taxonomy of prokaryotes. International Journal of Systematic and Evolutionary Microbiology, 2018, vol. 68, pp. 461-466.

23. GOST R 57446-2017. Nailuchshie dostupnye tekhnologii. Rekultivatsia narushennykh zemel $i$ zemelnykh uchastkov. Vosstanovlenie biologicheskogo raznoobrazia [State Standart R 57446-2017. Best available techniques. Disturbed lands reclamation. Restoration of biological diversity]. Moscow, Standartinform Publ., 2017. 28 p.

24. Altunina L.K. Kataliticheskie, sorbtsionnye, mikrobiologicheskie $i$ integrirovannye metody dlya zashity $i$ remediatsii okruzhayushchey sredy [Catalytic, sorption, microbiological and integrated methods for environmental protection and remediation]. Ed. by O.P. Taran, V.N. Parmon. Novosibirsk, SO PAN Publ., 2013. 298 p.

25. Nikitchuk K.L. Perspektivy vnedrenia traditsionnykh ekologicheskikh znaniy korennykh malochislennykh narodov $v$ praktiku okhrany okruzhayuschey sredy $i$ ratsionalnogo prirodopolzovaniya [Prospects for the integration of traditional environmental knowledge of small indigenous peoples into environmental protection and management]. Terra Humana, 2016, vol. 1 (38), pp. 87-91.

Received: 1 June 2020.

Information about the authors

Yulia A. Frank, Cand. Sc., head of laboratory, National Research Tomsk State University; lead engineer, «TomskNIPIneft» JSC; scientific vice-director «Darwin» LLC.

Ksenia L. Nikitchuk, senior lecturer, National Research Tomsk State University.

Alexey A. Sapega, master student, National Research Tomsk State University; technologist, «Darwin-Service» LLC. 
Evgenia A. Lukyanova, Cand. Sc., deputy director for quality, «Darwin» LLC.

Denis A. Ivasenko, senior lecturer, National Research Tomsk State University; director, «Darwin» LLC. Anton V. Kosov, director, «Darwin-Service» LLC.

Anna L. Gerasimchuk, Cand. Sc., senior researcher, National Research Tomsk State University. Nina S. Evseeva, Dr. Sc., head of department, National Research Tomsk State University. 